\title{
Long-run price performance of local and dual class IPOs in alternative investment market*
}

\author{
Abdul Wahid ${ }^{1}$, Muhammad Zubair Mumtaz ${ }^{2}$
}

\begin{abstract}
Earlier studies document that IPOs are underpriced in the short-run and underperformed in the long-run. In almost all studies, researchers analyze the IPO performance using the dataset from highly liquid markets. However, the pricing behavior of IPOs in the Alternative Investment Market (AIM) is different. There is a reason to expect the price performance of IPOs in the AIM to be significantly different from IPO performance in traditional markets mainly because of the diminished liquidity of AIM offerings as well as the meager disclosures required in comparison to traditional markets. To test our propositions, we select 292 IPOs listed on AIM during the period between 2001 and 2016 and apply the Extreme Bound Analysis (EBA) to determine the factors that cause longer-term performance. This study reports that investors in the alternative markets earn significant positive returns if the stock is held for three years, and the price variation is dependent upon the firm size. This illustrates that investment in smallsized firms seems more profitable as compared to those of large-sized firms in the AIM. Moreover, this study examines statistical evidence bearing on the question of whether early investors in IPOs can expect abnormal excess returns in the longrun.
\end{abstract}

Key words: IPOs, long-run price performance, extreme bounds analysis, alternative investment market

JEL classification: $G 12$, G14, C1

\footnotetext{
Received: 29-06-2019; accepted: 21-05-2020

1 Lecturer, NUML School of Business, National University of Modern Languages (NUML), Sector H-9, Islamabad, Pakistan. Scientific affiliation: financial economics. Phone: +923112211990. E-mail:abwahid@numl.edu.pk.

2 Associate Professor, National University of Sciences \& Technology (NUST), School of Social Sciences \& Humanities (S3H), Sector H-12, Islamabad, Pakistan. Scientific affiliation: financial markets and digitalization. Phone:+925190853566.E-mail: zubair@s3h.nust.edu.pk.
} 


\section{Introduction}

It is well-established evidence that IPOs are often underperformed in the long-run. Because the spread between the short-run and long-run share prices is almost large which is categorized as underperformance of new issues (Ali, 2017; Fine, Gleason, and Mullen, 2017; Mumtaz, Smith, and Ahmed, 2016). The level of underperformance varies across the nationality of the issuers and exchanges (Mudambi et al., 2012). Ritter, (1991) initially started a long-lasting debate that gave birth to various propositions purporting to explain the long-run underperformance. Researchers suggested that the spread reflects the prospects and opportunities facing the issuers (Loughran \& Ritter, 1995). Most of the prior literature is replete with analysis of IPO long-run pricing performance in the main markets; however, limited literature is available to evaluate the long-run pricing performance of IPOs in AIM. This study adds to the existing literature how IPOs behave on alternative markets in a wider horizon.

An important question arises as to how IPOs behave in the long-run issued in AIM as the dynamics of the market are different than the main markets. We can argue that firms don't require any specific financial record, the regulatory framework allows foreign companies to enlist their securities on AIM owing to low regulatory burden, no minimum capital requirements for the size or number of shareholding (Wahid, Mumtaz and Mantell, 2019), and only 22\% new issues were listed on the main market whereas $78 \%$ of new issues were listed in an alternative market during the past two decades (Wahid, Mumtaz and Mantell, 2020). Due to higher trading activities in AIM, optimistic investors may participate in the offering, thus, the value of IPO exhibits uncertainty regarding the existence of variation for optimistic and pessimistic investors (Miguel and Francisco, 2016). The flow of information in the long-run diverges the expectations of investors and corrects the price movements. With all these justifications, the purpose of this study is to examine how local and dual IPOs behave in the long-run.

This study aims to examine the research questions: (i) how can one characterize the long-run price performance of IPOs issued in the AIM? (ii) how does the divergence of opinion influence long-run performance? (iii) do market conditions affect the pricing dynamics? (iv) are the price dynamics of IPOs influenced by the size and price of the issue? and (v) what are the robust predictors that influence the long-run performance of unseasoned issues? This study reports that investors in the alternative markets earn significant positive returns if the stock is held for three years, and the price variation is dependent upon the firm size. In long-run board independence also plays a significant role. The findings of the study have also practical value for those investors who are especially interested in earning abnormal excess returns in an alternative market.

The rest of the paper is structured as follows. Section 2 elaborates the literary review focuses on the theoretical discourse on long-run IPOs returns and operating 
dynamics of AIM. Section 3 explains the econometric model. Section 4 describes the data, sample size and findings of the study. Section 5 discusses the findings and Section 6 concludes the study.

\section{Literature review}

This section reviews the underpinning theories that are important to describe the long-run price performance of the new issues. Long-run behavior indicates that IPOs underperform from one to three-year period. There are various reasons for the underperformance e.g. (a) window of opportunity hypothesis, (b) impresario or fads hypothesis, (c) divergence of opinion hypothesis, and (d) entrenchment theory. Moreover, this section focuses on the operating framework and the regulatory environment in the AIM.

\subsection{Theoretical framework on IPO underperformance}

In the literature of IPO performance, the third anomaly (i.e. underperformance of new issues) was introduced by Ritter, (1991). This was initiated as alonglasting debate and identified various propositions responsible for the long-run underperformance. The window of opportunity hypothesis develops the nexus between the timing of issuance and underperformance. It is generally argued that during the hot market period firms overprice their issues resulting in the yield low returns for the investors in the long run (Ritter, 1991). Similarly, Loughran and Ritter, (1995) also support the notion of the window of opportunity hypothesis which illustrates that to get the fruitful outcomes of the high IPO activity period, the firms manage to overprice their issues. In this way, newly listed firms also raise funds and investments from the market at excessive prices (Mumtaz et al., 2016). This excessive amount is raised without having any substantial growth prospects and opportunities (Lee, 2012; Loughran and Ritter, 1995). As a result, these issues would not be able to justify the high pricing, and the market adjusts their value with real valuation and pricing. Previous studies have widely documented the hot issue market and IPO underperformance (Ritter, 1998; Kaneko and Pettway, 2003; Khurshed, Kostas and Saadouni, 2016; Ali, 2017). The firms going public in the hot market are overly optimistic growth prospects and perform substantially worse than other IPOs (Mumtaz et al., 2016). Impresario or fads hypothesis explains that generally investment banks intentionally underprice their underwritten IPOs to generate more demand of their IPOs in the market, so that investors could get more return on a listing day (Mumtaz et al., 2016). With this perspective, these investment banks intend to create their positive and professional identity in the market that underwriters are giving good investment advice and proving profitable opportunities for investors. This hypothesis develops that initial returns and 
subsequent underperformance have a strong and direct relationship. This illustrates that higher underpricing leads to a higher probability of subsequent correction of share prices which subsequently results in underperformance of IPOs. Earlier studies have attempted to test the fads hypothesis in IPO market (Fama et al., 1969; Bondt and Thaler, 1985; Aggarwal and Rivoli, 1990; Aggarwal, Leal and Hernandez, 1993) and impresario hypothesis (Chepeta and Jardine, 2014) using the 'underpricing' as one of the explanatory variables in the regression. The divergence of opinion hypothesis explains the uncertainty about IPO which causes the overvaluation on the first trading and subsequent underperformance for the longrun. This hypothesis developed and empirically endorsed by Miller $(1977,2001)$ which illustrates that the divergence of opinion on the first trading day can generate more demand and higher overvaluation cause the IPO underperformance in the long-run. He found the strong and positive association between the magnitude of divergence of opinion among investors and the long-run performance of IPOs. The rationale of this theory is based on the optimistic views of the prospective investors about the IPOs that mostly optimistic investors tend to buy the IPOs from the market that pertain more divergent opinions about futuristic performance and worth of the firm. This also explains that uncertainty about futuristic performance and real worth of the firm gives birth to the difference of opinion among both the optimistic and pessimistic perspective investors, resulting in overvaluation on the first trading day. Subsequently, over time as realistic views and information flow in the market, the divergence of opinion tends to reduce and adjustment takes place in the prices, which results in underperformance. This evidence has been tested by prior studies (Miller, 2001; Kooli and J. M. Suret, 2004; Guo, Lev and Shi, 2006) using aftermarket price variability to determine the 'divergence of opinion hypotheses'. An entrenchment theory develops the relationship between the management and longrun performance. When managers gain power in the company, they may be able to use the firm in their own interests which eventually increases the ownership control, thus, entrenchment negatively influences the valuation of new issues in long-run. Earlier studies (Mazzola and Marchisio, 2002; Sahoo and Rajib, 2010) empirically found that entrenchment effect is likely to be more prevalent in family business which significantly underperform IPOs in the long run (Chahine, 2007). Post-issue promoter group holding (PIPH) is also used as a proxy for managerial entrenchment to test the entrenchment effect in measuring the long-run performance.

\subsection{The regulatory environment of the alternative market}

The AIM is a sub-market of the London Stock Exchange which was launched on 19 June 1995. This market allows smaller, less-viable companies to issue shares with a more flexible regulatory system than it is in force on the main market. Upon its launch, AIM consisted of only 10 companies valuing collectively at $£ 82.2$ million. By the end of 2017, more than 2.000 companies were actively traded in the sub- 
market, with an average market cap of $£ 80$ million per listing (Hore, 2016). AIM has also started to become an international exchange, often due to its low regulatory burden, especially concerning the US Sarbanes- Oxley Act. At this date only about a quarter of AIM-listed companies would qualify to be listed on a U.S. stock exchange even before the Sarbanes-Oxley Act (Doidge and Stulz, 2007).

The regulatory model of AIM is based on a comply-or-explain option that lets companies that are floated in AIM either comply with few rules or explain why it has decided not to comply with them. The purpose of this market was to facilitate and promote trading opportunities for small and medium enterprises (SMEs). During the past two decades, only $21.9 \%$ of new issues were listed on the LSE (known as the main market) whereas $78.1 \%$ listed on the alternative markets (Mendoza, 2008). There are few reasons to expect that the price behavior of firms listed on LSE and AIM are significantly different. First, no specific criterion is required to qualify for the listing on the AIM. Second, firms do not require any particular financial track record, and lastly, no minimum requirement in terms of size or number of shareholders (Mendoza, 2008). This phenomenon gives birth to new discourse that would have the same consequences in the short-run and longrun if the firm goes public in the sub-market? The difference in the institutional characteristics of the two markets i.e. the main market and AIM motivated us to identify the factors that affect IPO pricing dynamics in alternative markets. To explain the above theories, empirical research examines various determinants and proxies that are perceived to be related to the long-run performance of IPOs.

\section{Methodology}

\subsection{Econometric equation}

In this study, we use the Buy and Hold Abnormal Return (BHAR) technique to determine the long-run pricing performance of IPOs. Following Loughran and Ritter (1995), BHAR for firm $i$ at time $t$ is computed as:

$$
\begin{aligned}
& \left.B H A R_{i t}=\prod_{t=1}^{\tau}\left[1+R_{i t}\right]-1\right] \\
& \text { BHAR }_{i t}=\frac{1}{n} \sum_{i=1}^{n}\left[\prod_{t=1}^{T}\left[1+R_{i t}\right]-\prod_{t=1}^{T}\left[1+R_{m t}\right)\right]
\end{aligned}
$$

where $R_{i t}$ represents the return of stock $i$ at time $t$ and $R_{m t}$ indicates the return on the benchmark index (FTSE-AIM 100). To determine the market adjusted normal 
returns, the corresponding FTSE-AIM 100 is used as a benchmark index for each IPO firm. $n$ denotes the number of IPOs. We also identify the robust factors of longrun performance by developing the following equation:

$$
\begin{aligned}
\text { BHAR }= & \beta_{0}+\beta_{1}\left(\text { Up }_{i}\right)+\beta_{2}\left(\text { LDel }_{i}\right)+\beta_{3}\left(\text { Osub }_{i}\right)+\beta_{4}\left(\text { Offersize }_{i}\right)+ \\
& +\beta_{5}\left(\text { LIR R }_{i}\right)+\beta_{6}\left(\text { FinLev }_{i}\right)+\beta_{7}\left(\text { Firm }_{\text {s age }}\right)+\beta_{8}\left(\text { Firm size }_{i}\right)+ \\
& +\beta_{9}\left(\text { Mkt }- \text { Ret }_{i}\right)+\beta_{10}\left(\text { Mkt }- \text { vol }_{i}\right)+\beta_{11}\left(\text { crisis }_{i}\right)+\beta_{12}\left(\text { hot }_{i}\right)+ \\
& +\beta_{13}\left(\text { RIS }_{i}\right)+\beta_{14}\left(\text { Board }_{\text {size }}\right)+\varepsilon_{i}
\end{aligned}
$$

where Up is the first day underpricing of IPO and LDel is the listing delay which is the natural logarithm of the number of days separating the closing of subscription and the first day of trading. Osub (oversubscription) is the number of shares demanded by the number of shares offered and offer size is the number of shares issued multiplied by offer price. LIR is the ratio of long-term investment in total assets of the firm, FinLev (financial leverage) is calculated as the book value of long-term debt to total assets, a firm age is measured as the difference between the year of incorporation and going public and a firm size is the natural logarithm of the firm's total assets prior to IPO. Mkt-Ret (market return) is measured through FTSEAIM 100 value-weighted index over three months before IPO. Mkt-Ret (market return) is measured through FTSE-AIM 100 value-weighted index over three months before IPO. Mkt_volt (market volatility) is standard deviation of market return over 245 days prior to going public. PIMD is the ratio of share owned by management and external shareholders, PIDH is ratio of share owned by directors and external shareholders, RIS is the ratio of institutional shareholdingand board size is the ratio of independent non-executive director (INEDs) at the board.

\subsection{Statistical technique}

The decades of endeavors have been made to explore the predictor of the longrun price performance of IPOs so far by many researchers but the question is to examine the robustness of variables of interest. According to Cooley and Leroy (1981), economic theory does not intricate as to which variables should be kept constant while employing any statistical technique or model. To tackle this limitation, (Leamer, 1983; 1985) developed the Extreme Bound Analysis (EBA). Practically, this techniques was firstly used by Levine and Renelt (1992). The various parallel models have been developed and used but the reliability of these models was questionable? The EBA technique is a useful and reliable method that is used to test the sensitivity of the desired outcomes to specification changes. It also reduces the uncertainty of model fitness and validity and reliability (Leamer, 1985). This study is an attempt to examine the robust predictors that influence the long-run performance of IPOs in the secondary market. In line with the EBA, we develop the following regression model (Moosa and Cardak, 2006): 


$$
\begin{aligned}
& B H A R_{i t}=\beta_{0}+\sum_{i p=1}^{n} \beta_{c} X_{i p i}+\mu_{i} \\
& B H A R_{i t}=\beta_{0}+\sum_{i p=1}^{n} \delta_{c} X_{i p i}+\beta Q_{i}+\sum_{i p=1}^{m} \delta_{c} z_{i p i}+\mu_{i}
\end{aligned}
$$

We first estimate the coefficient of the variable of interest ' $Q$ ' of which sensitivity and robustness is tested. To examine the sensitivity and robustness of the explanatory variables, we applied hundreds of regressions to predict the value of the coefficient of the respective variable. On the other hand, fixed variable(s) [X] are included in every set of regression and variable of interest $Q$ and the set of $Z$ variables are chosen from a predetermined pool of combinations of sets. The entire calculation of EBA is based on the coefficient value of the variable of interest $Q$. To test the significance of the equal- weighted BHAR which is equal to zero, Lyon, Barber, and Tsai (1999), we used the skewness adjusted t-statistics:

$$
t=\sqrt{n} \times\left(s+\frac{1}{3} \hat{\gamma} s^{2}+\frac{1}{\sigma n} \hat{\gamma}\right)
$$

Where

$s=\frac{\overline{\mathrm{BHAR}_{t}}}{\sigma\left(\mathrm{BHAR}_{t}\right)}$ and $\hat{\gamma}=\frac{\sum_{i=1}^{n}\left(\mathrm{BHAR}_{i}-\overline{\mathrm{BHAR}_{t}}\right)^{3}}{n \sigma\left(\mathrm{BHAR}_{t}\right)^{3}}$

Where:

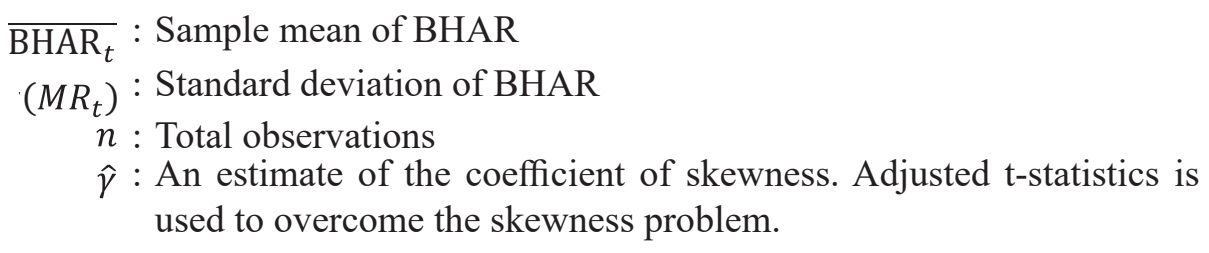

\section{Empirical data and analysis}

\subsection{Sample and data}

Our population of the study is divided into two main categories i.e. local and dualclass (cross-listed) IPOs in AIM during the period from July 1995 to December 2016. During this period, 2121 news issues have been placed on AIM including 1,713 local IPOs and 408 foreign firms issued IPOs on AIM for secondary listing (Figure 1 and Table 1). It is important to note that more than $75 \%$ of new issues 
were issued on the AIM and only 25\% in the main market during the 1995-2016 period. The total market capitalization of the submarket was $£ 87,903$ million and $£ 36,540$ million was collected from IPOs activities. The period of 2001 to 2010 was categorized as the hot activity period wherein more than $60 \%$ of IPOs issued in AIM.

Table 1: Position of IPOs in AIM (1995-2016)

\begin{tabular}{|c|c|c|c|}
\hline Year & $\begin{array}{l}\text { Number of } \\
\text { Companies }\end{array}$ & $\begin{array}{c}\text { Firm's Market Value } \\
(£ \mathrm{~m})\end{array}$ & $\begin{array}{c}\text { New Money Raised } \\
(\mathfrak{£ m})\end{array}$ \\
\hline 1995 & 16 & 208 & 69 \\
\hline 1996 & 95 & 1,757 & 504 \\
\hline 1997 & 72 & 844 & 299 \\
\hline 1998 & 37 & 603 & 185 \\
\hline 1999 & 59 & 674 & 274 \\
\hline 2000 & 179 & 4,667 & 1395 \\
\hline 2001 & 94 & 1,716 & 435 \\
\hline 2002 & 61 & 1,339 & 433 \\
\hline 2003 & 67 & 1,902 & 990 \\
\hline 2004 & 243 & 6,386 & 2,412 \\
\hline 2005 & 335 & 12,299 & 5,632 \\
\hline 2006 & 278 & 17,786 & 9,315 \\
\hline 2007 & 182 & 12,385 & 6,262 \\
\hline 2008 & 38 & 2,508 & 917 \\
\hline 2009 & 13 & 666 & 610 \\
\hline 2010 & 47 & 3,024 & 1,012 \\
\hline 2011 & 45 & 1,572 & 525 \\
\hline 2012 & 43 & 1,780 & 643 \\
\hline 2013 & 62 & 2,751 & 974 \\
\hline 2014 & 80 & 8,065 & 2,472 \\
\hline 2015 & 33 & 1,973 & 470 \\
\hline 2016 & 42 & 3,001 & 710 \\
\hline Total & 2121 & 87,903 & 36,540 \\
\hline
\end{tabular}

Note: This table depicts the IPOs market performance of AIM during the period of 1995 to 2016. During the period 2001-2010 more than $60 \%$ of IPOs were issued in AIM. The year 2000, and the period 2004-2007 are categorized as hot market activity where IPOs were made more than an average. 
Figure 1:

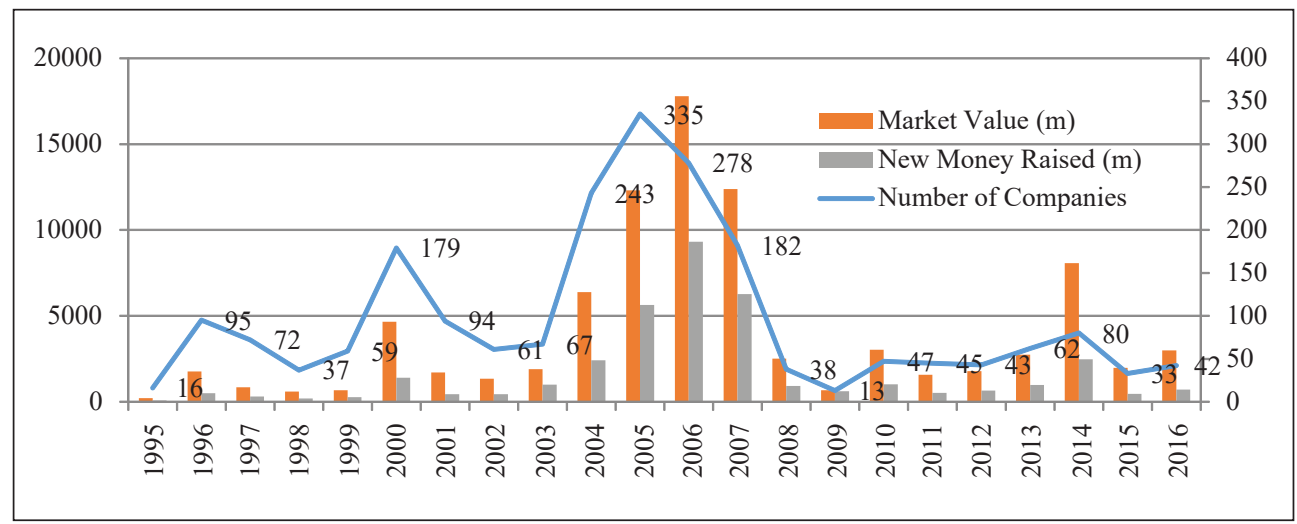

Source: London Stock Exchange statistics

To examine the long-run pricing performance, this study employs 320 IPOs (15\% of the overall population) listed on AIM during the period between 2001 and 2016 using systematic sampling. After the screening of the data, 292 firms were left to perform statistical analysis. We collected the monthly data for the long-run performance of IPOs from Yahoo finance and monthly historical data of LSE from their respective websites. Furthermore, firm related characteristics were obtained from the IPO prospectus and annual reports.

\subsection{Long-run pricing performance of overall sample}

In order to explain the long-run performance of various categories of IPOs, we divided our sample into three subgroups i.e. local incorporated IPOs, companies converted from private/mutual association to public limited and foreign companies. Table 2 depicts the average of the change in the earning that investors gain by passively putting their investments on the 1st day of trading, holding different categories of shares for the period of 36months. Secondly, to test the significance that the equal- and the value-weighted market return is equal to zero, Lyon, Barber, and Tsai (1999) suggested the skewness adjusted t-statistics has been applied. 
Abdul Wahid, Muhammad Zubair Mumtaz • Long-run price performance of local...

Table 2: Aftermarket BHAR of local, demutualized and cross-listed IPOs

\begin{tabular}{|c|c|c|c|c|c|c|c|c|c|}
\hline & \multicolumn{3}{|c|}{ Local IPOs } & \multicolumn{3}{|c|}{ Demutualized IPOs } & \multicolumn{3}{|c|}{ Cross-listed IPOs } \\
\hline & $\mathrm{N}$ & Mean & $\begin{array}{c}\text { Std. } \\
\text { Deviation }\end{array}$ & $\mathrm{N}$ & Mean & $\begin{array}{c}\text { Std. } \\
\text { Deviation }\end{array}$ & $\mathrm{N}$ & Mean & $\begin{array}{c}\text { Std. } \\
\text { Deviation }\end{array}$ \\
\hline BHAR1 & 280 & $17.19^{*}$ & 10.93 & 20 & $23.91 * *$ & 6.80 & 52 & $20.54 * *$ & 4.56 \\
\hline BHAR2 & 280 & $18.09 * *$ & 12.63 & 20 & $22.91 * *$ & 7.03 & 52 & $20.38 * *$ & 4.54 \\
\hline BHAR3 & 280 & $18.90 * *$ & 22.13 & 20 & $22.90 * *$ & 7.28 & 52 & $20.29 * *$ & 4.63 \\
\hline BHAR4 & 280 & $17.63 *$ & 22.66 & 20 & $23.83 * *$ & 8.04 & 52 & $20.41 * *$ & 4.85 \\
\hline BHAR5 & 280 & $17.57 *$ & 22.61 & 20 & $23.50 * *$ & 7.83 & 52 & $20.37 * *$ & 5.13 \\
\hline BHAR6 & 280 & $17.49^{*}$ & 23.71 & 20 & $22.73 * *$ & 8.16 & 52 & 20.47 & 5.38 \\
\hline BHAR7 & 280 & $18.39 * *$ & 24.70 & 20 & $22.27 * *$ & 8.35 & 52 & 20.55 & 5.64 \\
\hline BHAR8 & 280 & $19.14 * *$ & 26.50 & 20 & $21.98 * *$ & 8.38 & 52 & 20.50 & 5.57 \\
\hline BHAR9 & 269 & $19.78 * *$ & 27.34 & 20 & $22.21 * *$ & 8.59 & 52 & 20.45 & 5.65 \\
\hline BHAR10 & 269 & $19.28 * *$ & 28.83 & 20 & $22.69 * *$ & 8.63 & 52 & 20.28 & 5.59 \\
\hline BHAR11 & 264 & $19.54 * *$ & 27.89 & 20 & $22.60 * *$ & 9.10 & 52 & 19.97 & 5.79 \\
\hline BHAR12 & 260 & $18.05^{*}$ & 28.40 & 20 & $22.90 * *$ & 8.85 & 52 & 19.90 & 6.02 \\
\hline BHAR13 & 259 & 16.55 & 26.00 & 20 & $22.89 * *$ & 8.84 & 52 & $20.00 *$ & 6.17 \\
\hline BHAR14 & 257 & 15.82 & 22.69 & 20 & $22.57 * *$ & 9.04 & 52 & 19.97 & 6.40 \\
\hline BHAR15 & 253 & 15.69 & 23.62 & 20 & $22.46^{* *}$ & 8.74 & 52 & 19.78 & 6.44 \\
\hline BHAR16 & 250 & 16.31 & 24.19 & 20 & $22.66 * *$ & 7.97 & 52 & 19.76 & 6.78 \\
\hline BHAR17 & 250 & 17.01 & 27.92 & 20 & $22.27 * *$ & 8.32 & 52 & 19.97 & 7.20 \\
\hline BHAR18 & 248 & 15.13 & 26.98 & 20 & $22.01 * *$ & 8.25 & 52 & $20.13 *$ & 7.31 \\
\hline BHAR19 & 248 & 14.09 & 26.72 & 20 & $21.97 * *$ & 8.02 & 52 & $20.19^{*}$ & 7.42 \\
\hline BHAR20 & 244 & 14.54 & 27.99 & 20 & $21.88 * *$ & 7.91 & 52 & $20.40^{*}$ & 7.59 \\
\hline BHAR21 & 241 & 13.67 & 29.04 & 20 & $21.60 * *$ & 7.83 & 52 & $20.61 *$ & 7.83 \\
\hline BHAR22 & 241 & 13.79 & 28.33 & 20 & $21.50 * *$ & 8.17 & 52 & $20.53^{*}$ & 7.91 \\
\hline BHAR23 & 240 & 13.61 & 27.38 & 20 & $21.44 * *$ & 8.79 & 52 & $20.59 *$ & 7.85 \\
\hline BHAR24 & 240 & 12.78 & 28.07 & 20 & $21.59 * *$ & 9.07 & 52 & $20.83^{*}$ & 8.00 \\
\hline BHAR25 & 238 & 13.10 & 29.04 & 20 & $21.92 * *$ & 9.47 & 52 & $20.87 *$ & 8.37 \\
\hline BHAR26 & 238 & 18.29 & 60.12 & 20 & $21.96 * *$ & 9.96 & 52 & $20.78^{*}$ & 8.49 \\
\hline BHAR27 & 226 & 11.95 & 30.31 & 20 & $21.47 * *$ & 11.62 & 52 & $20.60 *$ & 8.43 \\
\hline BHAR28 & 226 & 13.18 & 31.77 & 20 & $21.58 * *$ & 11.63 & 52 & $20.82 *$ & 8.63 \\
\hline BHAR29 & 224 & 12.60 & 32.04 & 20 & $21.14 * *$ & 11.98 & 52 & $20.71 *$ & 8.73 \\
\hline BHAR30 & 223 & 13.13 & 32.48 & 20 & $21.02 * *$ & 12.11 & 52 & $20.43^{*}$ & 8.59 \\
\hline BHAR31 & 223 & 13.00 & 32.34 & 20 & $20.65 * *$ & 12.36 & 52 & $20.67 *$ & 8.82 \\
\hline BHAR32 & 222 & 13.10 & 33.24 & 20 & $20.43 * *$ & 11.99 & 52 & $21.09 * *$ & 9.50 \\
\hline BHAR33 & 222 & 13.32 & 33.55 & 20 & 19.64* & 11.77 & 52 & $21.14 * *$ & 9.52 \\
\hline BHAR34 & 221 & 13.76 & 34.15 & 20 & $19.35^{*}$ & 11.49 & 52 & $21.14 * *$ & 9.74 \\
\hline BHAR35 & 221 & 12.89 & 34.06 & 20 & $19.34 *$ & 11.58 & 52 & $21.32 * *$ & 10.04 \\
\hline BHAR36 & 220 & 11.92 & 33.78 & 20 & $18.79^{*}$ & 11.89 & 52 & $21.44 * *$ & 10.55 \\
\hline
\end{tabular}

Note: This table exhibits long-run price performance of a sample of 292 that consists of 220 newly listed IPOs, 20 demutualized firm's IPOs, and 52 Cross-listed IPOs listed on the AIM from 2001 to 2016. To test the significance skewness adjusted t-statistics is used. $*$ and $* *$ represent significance level at the 1 , and $5 \%$ respectively.

Source: Authors' calculations 
In, local IPOs investor earns (BHAR $=17 \%$ to $20 \% \mathrm{p}<0.05)$ in short-run period but in long-run, diminishing trend is observed which reduces earning till $11 \%$ $(\mathrm{p}>0.05)$. Likewise, in demutualized IPOs, the same diminishing trend in the long-run has been observed from $23 \%$ to $19 \%$ but these returns are significant at $95 \%(\mathrm{p}<0.05)$. On the other hand, investors earn significant abnormal returns (BHAR $=20 \%$ to $22 \%, \mathrm{p}<0.05)$ in cross-listed IPOs, and the uprising trend is observed from the short- to long-run period. It is further deduced that investors earn more returns by investing in demutualized IPOs relative to local IPOs in the long-run period. Besides, investors do enjoy more returns those invested their savings in cross-listed IPOs as compared to local and demutualized IPOs in AIM holding for 36 months.

\subsection{Long-run pricing performance of different industries}

Further to explain the long-run price performance of various industries, we divided our sample on the basis of industries. Table 3 depicts the comparative analysis of the long-run pricing performance of IPOs of various industries listed on AIM. Findings of the study reveal that mining, oil and gas, and electricity producers report the highest return $(\mathrm{BHAR}=23.51 \%, 22.50 \%$ and $25.51 \%, \mathrm{p}<0.05)$ respectively in the short-term period as compared to other industries. Likewise, investors earn more returns in the long-run period by investing in media and telecom, industrial and construction material and oil and gas industries (BHAR $=25.49 \%, 22.32 \%$, and $24.26 \% \mathrm{p}<0.05)$ respectively. 
Abdul Wahid, Muhammad Zubair Mumtaz • Long-run price performance of local...

Table 3: Industry and long-run IPOs performance

\begin{tabular}{|c|c|c|c|c|c|c|c|}
\hline Sector & BHAR1 & BHAR6 & BHAR12 & BHAR18 & BHAR24 & BHAR30 & BHAR36 \\
\hline \multirow{2}{*}{ Mining } & $23.51 * *$ & $23.41 * *$ & $23.80 * *$ & 19.06 & 18.48 & 16.09 & 16.27 \\
\hline & $(8.95)$ & (12.50) & $(22.05)$ & $(24.11)$ & $(29.23)$ & $(27.88)$ & $(24.88)$ \\
\hline \multirow{2}{*}{ Others } & $20.25 * *$ & $24.18 * *$ & $19.74 *$ & $24.77 * *$ & $24.15^{* *}$ & $23.02 * *$ & $18.60 *$ \\
\hline & (7.76) & $(15.55)$ & (19.62) & $(32.83)$ & (31.33) & $(35.25)$ & $(34.49)$ \\
\hline \multirow{2}{*}{ Media and Telecom } & $21.56 * *$ & $20.69 *$ & $21.30 * *$ & $21.26^{* *}$ & $21.37 * *$ & $28.10^{* *}$ & $25.49 * *$ \\
\hline & $(8.62)$ & $(10.50)$ & (19.44) & $(24.00)$ & $(26.36)$ & $(30.74)$ & $(38.69)$ \\
\hline \multirow{2}{*}{$\begin{array}{l}\text { Software and } \\
\text { computer }\end{array}$} & $21.96 * *$ & $20.34 *$ & $26.31 * *$ & $24.78^{* *}$ & $21.45 * *$ & 17.27 & 15.21 \\
\hline & $(6.65)$ & (10.47) & (18.24) & $(23.27)$ & (21.97) & $(27.02)$ & $(28.25)$ \\
\hline \multirow{2}{*}{ Travel services } & 15.81 & $19.98 *$ & $25.32 * *$ & $27.17 * *$ & $26.65 * *$ & $20.96^{* *}$ & 17.81 \\
\hline & $(5.33)$ & (12.07) & (16.64) & $(29.69)$ & $(34.26)$ & $(32.28)$ & $(26.01)$ \\
\hline \multirow{2}{*}{ Support Services } & $21.65 * *$ & $18.44^{*}$ & 17.33 & 10.50 & 9.06 & 10.92 & 15.71 \\
\hline & $(8.77)$ & (14.69) & $(21.44)$ & $(21.75)$ & (21.59) & $(27.30)$ & (41.59) \\
\hline \multirow{2}{*}{$\begin{array}{l}\text { Industrial and } \\
\text { Construction } \\
\text { Material }\end{array}$} & $21.67 * *$ & $22.09 * *$ & $28.72 * *$ & $25.99 * *$ & $21.39 * *$ & $25.98 * *$ & $22.32 * *$ \\
\hline & (7.11) & $(12.21)$ & $(21.79)$ & $(27.64)$ & $(28.17)$ & $(35.26)$ & $(31.69)$ \\
\hline \multirow{2}{*}{ Real Estate } & 14.32 & $24.56^{* *}$ & $26.61 * *$ & $29.61 * *$ & 11.77 & 18.36 & 17.73 \\
\hline & (19.04) & $(12.81)$ & $(17.10)$ & $(34.41)$ & (38.93) & $(46.86)$ & $(48.64)$ \\
\hline \multirow{2}{*}{$\begin{array}{l}\text { Pharmaceuticals and } \\
\text { Health care }\end{array}$} & $21.84 * *$ & $22.14 * *$ & $19.39 *$ & 16.35 & 13.42 & 13.35 & 4.49 \\
\hline & $(8.86)$ & (14.34) & $(16.27)$ & $(17.63)$ & $(21.40)$ & $(33.78)$ & $(23.71)$ \\
\hline \multirow{2}{*}{ Financial Services } & $21.07 * *$ & $18.53^{*}$ & $20.84 * *$ & $20.00^{*}$ & 17.23 & $23.77 * *$ & 16.71 \\
\hline & $(8.76)$ & $(8.90)$ & $(20.81)$ & $(28.54)$ & $(26.25)$ & $(35.98)$ & $(27.95)$ \\
\hline \multirow{2}{*}{$\begin{array}{l}\text { Electronic } \\
\text { and Electrical } \\
\text { Equipment }\end{array}$} & $21.33 * *$ & $21.79 * *$ & $30.63 * *$ & 18.57 & 14.36 & 17.18 & $19.37 *$ \\
\hline & $(6.06)$ & $(7.58)$ & (24.89) & $(21.78)$ & $(22.61)$ & $(20.30)$ & $(23.57)$ \\
\hline \multirow{2}{*}{ Oil and Gas sector } & $22.50 * *$ & $22.26 * *$ & $22.40 * *$ & $27.03 * *$ & $26.57 * *$ & $26.90 * *$ & $24.26^{* *}$ \\
\hline & $(7.25)$ & (12.68) & $(16.66)$ & $(27.27)$ & $(24.23)$ & $(37.49)$ & $(30.10)$ \\
\hline \multirow{2}{*}{ Chemical } & 18.80 & $19.34 *$ & $27.87 * *$ & $26.08^{* *}$ & $19.50 *$ & $18.86^{*}$ & 8.91 \\
\hline & $(12.01)$ & $(22.90)$ & $(33.02)$ & $(31.40)$ & $(24.27)$ & $(33.25)$ & $(28.94)$ \\
\hline \multirow{2}{*}{ Electricity Producer } & $25.51 * *$ & $23.84 * *$ & $25.10 * *$ & $25.09 * *$ & $21.03 * *$ & 13.28 & 10.97 \\
\hline & (7.64) & (13.69) & $(16.01)$ & (24.29) & (33.77) & $(38.22)$ & $(17.96)$ \\
\hline
\end{tabular}

Note: This table exhibits long-run price performance IPOs of various industries listed on the AIM from 2001 to 2016. To test the significance, skewness adjusted t-statistics is used.

* and ** represent significance level at the 1 , and $5 \%$ respectively.

Source: Authors' calculations 
Other industries such as software, travel services, support services, pharmaceutical, financial services, and chemical industries produce low returns as compared to mining, oil and gas, and electricity in short-run and media and telecom, industrial and construction material and oil and gas industries in the long-run period.

\subsection{Long-run pricing performance and market condition}

Table 4 reveals the long-run pricing performance of various categories of IPOs which were issued in hot-where IPOs were issued more than average and cold market period. Investors earn more returns in hot market period (BHAR $=23 \%$ to $25 \%, \mathrm{p}<0.05)$, and (BHAR $=21 \%$ to $24 \%, \mathrm{p}<0.05)$, in cold market $(17 \%$ to $19 \%$, $\mathrm{p}<0.05)$ and $(\mathrm{BHAR}=12 \%$ to $16 \%, \mathrm{p}<0.05)$, in short-term and long-term period respectively.

Table 4: Market condition and long-run IPOs performance

\begin{tabular}{|l|r|r|r|r|r|r|r|}
\hline Market Condition & \multicolumn{1}{|c|}{ BHAR1 } & BHAR6 & BHAR12 & BHAR18 & BHAR24 & BHAR30 & BHAR36 \\
\hline \multirow{2}{*}{ Cold Market } & $17.829 * *$ & $18.848^{* *}$ & $20.577^{* *}$ & $19.343 * *$ & $16.556^{*}$ & $16.247 *$ & $12.920^{*}$ \\
\cline { 2 - 8 } & $(8.42)$ & $(12.86)$ & $(20.00)$ & $(26.94)$ & $(28.65)$ & $(32.92)$ & $(31.95)$ \\
\hline \multirow{2}{*}{ Hot Market } & $25.109 * *$ & $23.878^{* *}$ & $25.03 * *$ & $23.86 * *$ & $21.54 * *$ & $24.92 * *$ & $21.19 * *$ \\
\cline { 2 - 8 } & $(7.50)$ & $(11.38)$ & $(19.89)$ & $(25.61)$ & $(24.69)$ & $(32.93)$ & $(28.99)$ \\
\hline
\end{tabular}

Note: This table exhibits long-run pricing behavior of IPOs listed on AIM during the period of hot and cold market. This also depicts the window of opportunity hypothesis. To test the significance, skewness adjusted t-statistics is used. * and ** represent significance level at the 1 , and $5 \%$ respectively.

Source: Authors' calculations

It deduces that BHAR increases as market sentiment are in hot activity relative to cold activity period. This supports the window of opportunity hypothesis explaining that during the hot IPO market period firms overprice their issues resulting in the yield low returns for the investors in the long run (Ritter, 1991). As a consequence, IPOs underprice in the short-run which results in subsequent underperformance. This evidence is positive and strongly influences each other. 


\subsection{Long-run pricing performance and offer price}

Table 5 illustrates the size of the issue price and the long-run price performance of IPOs. We classify the IPOs into issue price size quartile based on the range of IPOs issue price in AIM from 2001 to 2016. It deduces that medium-size offer price i.e. second and third quartile produces more returns $(\mathrm{BHAR}=22.39 \%, 21.83 \%$, $\mathrm{P}<0.05)$ respectively in short-run and $(\mathrm{BHAR}=19.02 \%, 17.86 \%, \mathrm{P}<0.05)$ respectively in long-run relative to low offer price and high offer price.

Table 5: Issue price and long-run IPOs performance

\begin{tabular}{|l|r|r|r|r|r|r|r|}
\hline \multicolumn{1}{|c|}{ Issue Price } & BHAR1 & BHAR6 & BHAR12 & BHAR18 & BHAR24 & BHAR30 & BHAR36 \\
\hline \multirow{2}{*}{$\begin{array}{l}\text { Issue Price } \\
\leq 25\end{array}$} & $20.579 * *$ & $19.808 * *$ & $19.596 * *$ & $18.157 * *$ & $14.992 *$ & $14.042 *$ & 12.753 \\
\cline { 2 - 8 } & $(8.63)$ & $(11.63)$ & $(17.87)$ & $(24.57)$ & $(26.00)$ & $(27.39)$ & $(29.06)$ \\
\hline $\begin{array}{l}\text { Issue Price } \\
>25 \text { and }<70\end{array}$ & $22.396 * *$ & $20.384 * *$ & $25.098 * *$ & $22.722 * *$ & $19.162 * *$ & $23.058 * *$ & $19.020 *$ \\
\cline { 2 - 8 } & $(7.65)$ & $(12.63)$ & $(22.38)$ & $(27.23)$ & $(24.22)$ & $(36.59)$ & $(32.25)$ \\
\hline $\begin{array}{l}\text { Issue Price } \\
>70 \text { and }<120\end{array}$ & $21.833 * *$ & $22.729 * *$ & $21.107 * *$ & $20.063 * *$ & $21.617 * *$ & $22.750 * *$ & $17.862 *$ \\
\cline { 2 - 8 } & $(7.21)$ & $(12.69)$ & $(19.19)$ & $(26.64)$ & $(27.56)$ & $(33.71)$ & $(29.84)$ \\
\hline \multirow{2}{*}{ Issue Price $>120$} & $20.176 * *$ & $22.833 * *$ & $24.494 * *$ & $25.015 *$ & $20.978 *$ & $22.195 * *$ & $17.916 *$ \\
\cline { 2 - 8 } & $(11.215)$ & $(12.719)$ & $(19.57)$ & $(26.96)$ & $(30.65)$ & $(33.66)$ & $(31.74)$ \\
\hline
\end{tabular}

Note: This table exhibits nexus between issue price and long-run price performance. This also depicts the ex-ante uncertainty hypothesis. To test the significance, skewness adjusted t-statistics is used. * and ** represent significance level at the 1 , and $5 \%$ respectively.

Source: Authors' calculations

Generally, issues are floated at fixed price mechanism in AIM so that investors may prefer to invest in IPOs where offer price is in medium range - neither lowest nor the highest because the issuer gathers pricing information from institutional investors and individual investors with a high net worth through a bidding process to build interest in investment in the company's shares.

\subsection{Long-run pricing performance and firms' market capitalization}

Table 6 explains the long-run price performance based on the firm's market capitalization in AIM. We classify the IPOs into market capitalization size quartile based in AIM from 2001 to 2016. Small size firms report higher abnormal returns $(\mathrm{BHAR}=23.01 \%$, to $22.52 \%, \mathrm{P}<0.05)$ in short-run but in long-run performance of large size firms was on the higher side $(\mathrm{BHAR}=22.39 \%, 21.83 \%, \mathrm{P}<0.05)$ relative to low and medium-size firm. 
Abdul Wahid, Muhammad Zubair Mumtaz • Long-run price performance of local...

Table 6: Market share of firm and long-run IPOs performance

\begin{tabular}{|c|c|c|c|c|c|c|c|}
\hline Market Capitalization & BHAR1 & BHAR6 & BHAR12 & BHAR18 & BHAR24 & BHAR30 & BHAR36 \\
\hline \multirow{2}{*}{$\begin{array}{l}\text { Market Capitalization } \\
\leq 23(£ \mathrm{~m})\end{array}$} & $23.017 * *$ & $22.200 * *$ & $22.521 * *$ & $21.164 * *$ & $18.388^{*}$ & $18.378^{*}$ & 14.299 \\
\hline & (7.41) & (13.09) & $(21.11)$ & $(26.24)$ & $(27.33)$ & $(34.30)$ & $(29.77)$ \\
\hline \multirow{2}{*}{$\begin{array}{l}\text { Market Capitalization } \\
>23.46 \text { and }<50.59 \\
(£ \mathrm{~m})\end{array}$} & $19.351 *$ & $18.763^{*}$ & $18.815^{*}$ & $20.117 * *$ & 15.523 & $20.986^{*}$ & $18.055^{*}$ \\
\hline & $(11.26)$ & $(10.52)$ & (19.36) & $(25.01)$ & (23.76) & (32.07) & $(32.04)$ \\
\hline \multirow{2}{*}{$\begin{array}{l}\text { Market Capitalization } \\
>50.59 \text { and }<107.33 \\
(£ \mathrm{~m})\end{array}$} & $20.662 * *$ & $21.760 * *$ & $25.665 * *$ & $23.004 * *$ & $21.966 * *$ & $20.112 * *$ & 17.605 \\
\hline & $(6.97)$ & (12.89) & $(17.83)$ & $(28.41)$ & $(28.63)$ & (30.18) & (33.85) \\
\hline \multirow{2}{*}{$\begin{array}{l}\text { Market Capitalization } \\
>107.33(£ \mathrm{~m})\end{array}$} & $19.048^{* *}$ & $21.554 * *$ & $26.967 * *$ & $23.425^{* *}$ & $23.632 * *$ & $27.759^{* *}$ & $23.879 * *$ \\
\hline & $(9.44)$ & (12.20) & (19.07) & $(27.32)$ & $(28.48)$ & $(34.81)$ & $(27.48)$ \\
\hline
\end{tabular}

Note: This table displays market volume of the firm i.e. small, medium and large size firm and long-run pricing pattern. This also depicts the signaling hypothesis To test the significance, skewness adjusted t-statistics is used. * and ** represent significance level at the 1 , and $5 \%$ respectively.

Source: Authors' calculations

This support "signaling hypothesis" that sometimes large firms intentionally underprice/overprice their issuance to differentiate their status in the market from small size firm. As a consequence, IPOs underprice in the short-run result in subsequent underperformance in the long-run. Various studies for instance (Fine et al., 2017; Pandya, 2016) reported that firm size does affect the longrun price performance of IPOs. Similarly, in the AIM market, firm size has a significant impact on underpricing (Amini and Keasey, 2013) and subsequent underperformance of IPOs in the long-run (Acedo-Ramírez and Ruiz-Cabestre, 2016).

\subsection{Long-run pricing performance and offer size}

Table 7 illustrates the impact of offer size on the long-run price performance of IPOs in AIM exhibiting that the IPOs in three of the four categories based on offer size and longer-term performance over three years. Small offer size issues earn more returns $(\mathrm{BHAR}=22.90 \%$ to $21.72 \%, \mathrm{P}<0.05)$ relative to medium size and large size issue proceeds in short-run period but on flip side large issue proceeds earns higher returns $(\mathrm{BHAR}=25.35 \%$ to $26.31 \%, \mathrm{P}<0.05)$ relative to medium size and small size issue proceeds in long-run. 
Table 7: Offer size and long-run IPOs performance

\begin{tabular}{|c|c|c|c|c|c|c|c|}
\hline Offer Size & BHAR1 & BHAR6 & BHAR12 & BHAR18 & BHAR24 & BHAR30 & BHAR36 \\
\hline \multirow{2}{*}{ Offer Size $\leq 3(£ \mathrm{~m})$} & $22.902 * *$ & $20.997 * *$ & $21.681 * *$ & $21.721 * *$ & 17.205 & 15.308 & 11.629 \\
\hline & $(7.71)$ & $(13.72)$ & (19.90) & $(26.37)$ & $(26.06)$ & $(30.12)$ & $(26.43)$ \\
\hline \multirow{2}{*}{$\begin{array}{l}\text { Offer Size } \\
>3 \text { and }<8.0114(£ \mathrm{~m})\end{array}$} & $22.188 * *$ & $22.386^{* *}$ & $23.528 * *$ & $21.390 * *$ & 19.077 & $23.375^{* *}$ & 17.200 \\
\hline & $(7.49)$ & $(12.72)$ & $(22.82)$ & $(28.12)$ & $(29.42)$ & $(40.76)$ & $(35.57)$ \\
\hline \multirow{2}{*}{$\begin{array}{l}\text { Offer Size }>8.0114 \\
\text { and }<18.26(£ \mathrm{~m})\end{array}$} & $20.038^{* *}$ & $21.175^{* *}$ & $20.515^{* *}$ & 18.618 & 14.479 & 17.589 & 16.925 \\
\hline & $(11.63)$ & $(11.29)$ & $(18.00)$ & $(23.55)$ & $(22.81)$ & $(27.43)$ & $(27.79)$ \\
\hline \multirow{2}{*}{ Offer Size > $18.26(£ m)$} & $19.657 * *$ & $20.438^{* *}$ & $25.291 * *$ & $24.195 * *$ & $25.356^{* * *}$ & $26.319 * *$ & $22.863 * *$ \\
\hline & $(7.50)$ & (11.62) & (19.11) & $(27.38)$ & $(28.31)$ & $(32.62)$ & $(32.80)$ \\
\hline
\end{tabular}

Note: This table shows the interrelationship between magnitude of offer size and long-run price performance which further elaborates the ex-ante uncertainty hypothesis. To test the significance, skewness adjusted $\mathrm{t}$-statistics is used. *** represent significance level at the 1 , and $5 \%$ respectively.

Source: Authors' calculations

This evidence supports the ex-ante uncertainty hypothesis because issues yielding the lowest gross proceeds underperform significantly. This also elaborates that large offer size needs more money to be used for the development and growth of the firm as well as investing in optimal investment opportunities resulting in higher returns in the long-run.

\subsection{Long-run pricing performance and initial returns}

Table 8 exhibits initial returns earned by investors result in a subsequent adjustment in the long-run in AIM. Lower underpricing in short-run result in higher returns in long-run (BHAR $=18.40 \%$ to $23.20 \%, \mathrm{P}<0.05$ ) relative to higher underpricing in short-run (BHAR $=08.49 \%$ to $16.38 \%, \mathrm{P}<0.05$ ). This support Impresario or fads hypothesis which explains that firm intentionally underprices their underwritten IPOs to generate more demand of their IPOs in the market, so that investor could get more return on first day trading in market (Mumtaz et al., 2016). 
Abdul Wahid, Muhammad Zubair Mumtaz • Long-run price performance of local...

Table 8: Initial underpricing and long-run IPOs performance

\begin{tabular}{|l|r|r|r|r|r|r|r|}
\hline \multicolumn{1}{|c|}{ Underpricing } & BHAR1 & BHAR6 & BHAR12 & BHAR18 & BHAR24 & BHAR30 & BHAR36 \\
\hline $\begin{array}{l}\text { Underpricing } \\
\leq-2.92 \%\end{array}$ & $22.519 * *$ & $23.262^{* *}$ & $26.323^{* *}$ & $25.622^{* *}$ & $24.081^{* *}$ & $27.264 * *$ & $23.201 * *$ \\
\cline { 2 - 8 } & $(9.67)$ & $(12.72)$ & $(22.79)$ & $(27.95)$ & $(28.95)$ & $(36.11)$ & $(34.46)$ \\
\hline $\begin{array}{l}\text { Underpricing } \\
>-2.93 \% \text { and }<1.300 \%\end{array}$ & $20.879 * *$ & $20.840^{* *}$ & $21.836^{* *}$ & $21.071 * *$ & 19.334 & 18.362 & 18.406 \\
\cline { 2 - 8 } & $(6.36)$ & $(8.64)$ & $(14.43)$ & $(17.21)$ & $(16.74)$ & $(17.39)$ & $(18.93)$ \\
\hline $\begin{array}{l}\text { Underpricing } \\
>1.300 \% \text { and }<9.69 \%\end{array}$ & $20.375 * *$ & $21.428 * *$ & $23.502 * *$ & $21.996 * *$ & 16.803 & 19.887 & 16.380 \\
\cline { 2 - 8 } & $(9.14)$ & $(12.75)$ & $(21.35)$ & $(31.70)$ & $(27.13)$ & $(37.21)$ & $(33.60)$ \\
\hline \multirow{2}{*}{ Underpricing $>9.69 \%$} & $21.435 * *$ & $19.168 *$ & 18.588 & 16.671 & 15.131 & 15.330 & 8.498 \\
\cline { 2 - 8 } & $(9.51)$ & $(14.84)$ & $(19.96)$ & $(25.64)$ & $(32.38)$ & $(36.97)$ & $(32.16)$ \\
\hline
\end{tabular}

Note: This table depicts the interrelationship between initial returns of IPOs and long-run price performance which further explain the dimension of 'divergence of opinion hypotheses' and impresario or fads hypothesis. To test the significance, skewness adjusted t-statistics is used. * and ** represent significance level at the 1 , and $5 \%$ respectively.

Source: Authors' calculations

This hypothesis also elaborates that the initial return and subsequent underperformance are strongly and positively associated with each other. Generally, it is also observed in previous literature for instance (Mumtaz et al., 2016) that the higher the underpricing on the first trading day leads to higher underperformance in long-run.

\subsection{Descriptive analysis and Pearson correlations}

The descriptive analysis of outcome and criterion variables depicts that longrun return (BHAR) of selected sample $14 \%$ on an average and short-run returns (MAAR) were 10\% (Table 9). On average 21 days were observed in listing IPOs on the alternative market which indicates that listing process of AIM is not complicated as compared to the main markets. Firm size and offer size are reported an average 42 million pounds and 17 million pounds respectively which indicate that most firms were SMEs. These firms were an average $31 \%$ levered with small ages $(<2$ years $)$ at the time of offering. This evidence illustrates that majority of small IPOs are incorporated and working in the AIM. According to Amini, Keasey, and Hudson (2012), access to market-based equity finance is easier for these small firms in capital as well as financial market. Likewise, market returns were between an average $2 \%$ and $-4 \%$ in AIM with small volatility (-0.491) indicating stability of the market. The mode values of dummy variables comprise crisis period and hot market. During the crisis period, few issues were listed whereas firms preferred to issue IPOs in the hot market activity. 
Abdul Wahid, Muhammad Zubair Mumtaz $\bullet$ Long-run price performance of local...

0
0
$\vdots$
0
0
0
0
0
0
0
0
0
0
0
0
0 Zb. rad. Ekon. fak. Rij. • 2020 • vol. $38 \cdot$ no. $1 \cdot 71-100$

* ఉ.

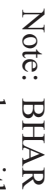

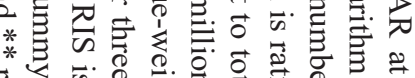

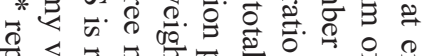

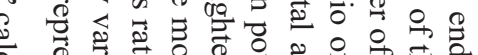

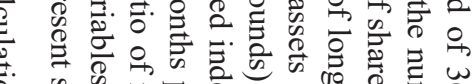

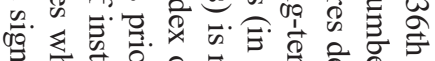

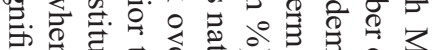

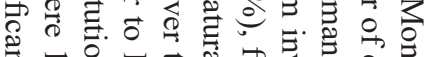

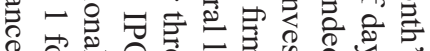

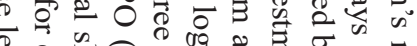

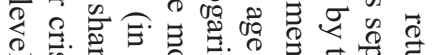

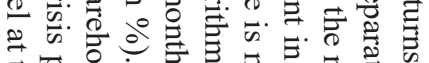

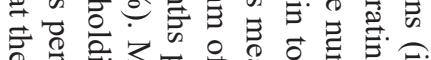

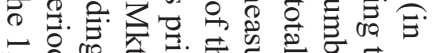

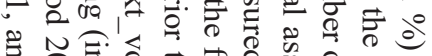

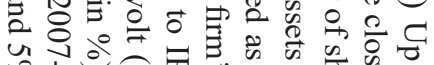
गें के

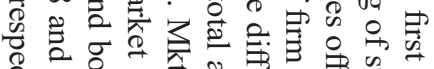

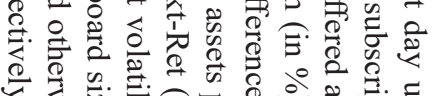

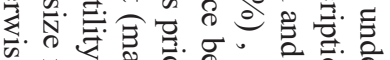
त. ○ ज.

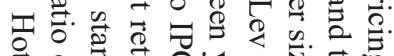

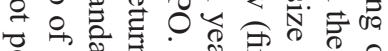

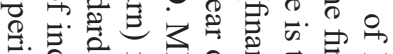

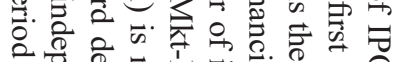
ज.

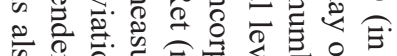

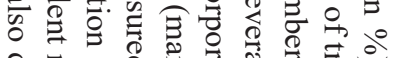

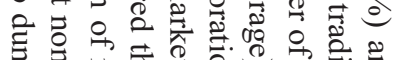

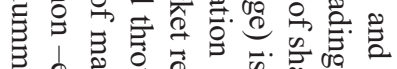

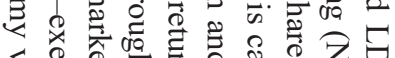

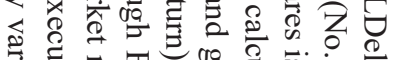

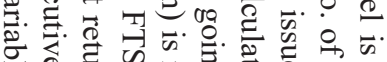

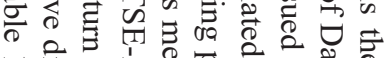
कृ

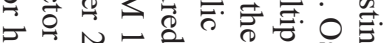

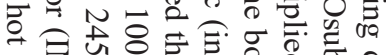

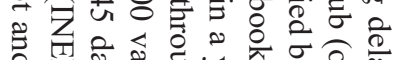

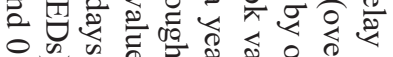

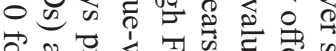

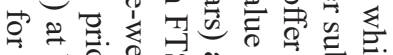
ร

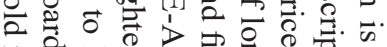

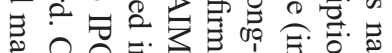
突

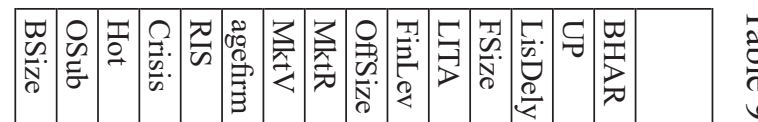

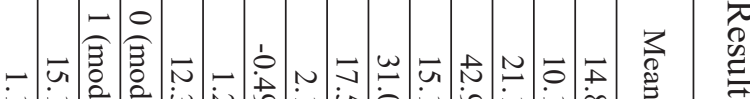

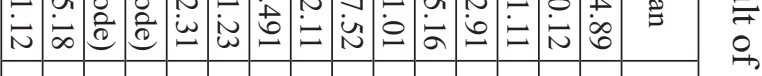
-

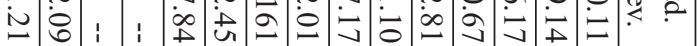

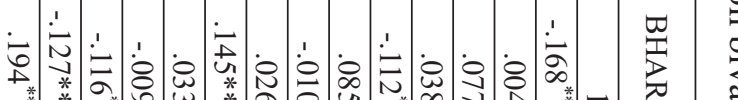

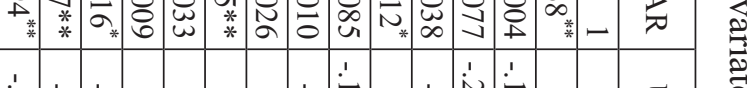

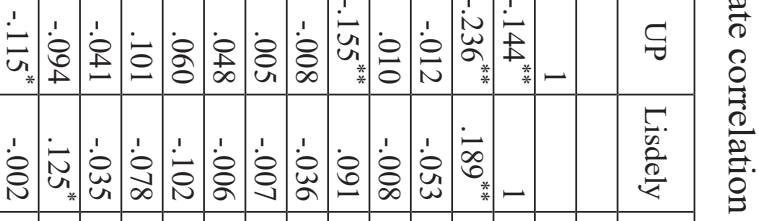

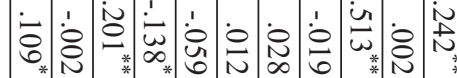

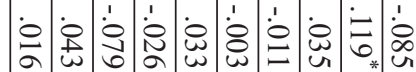

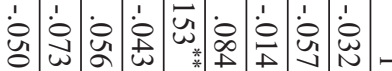

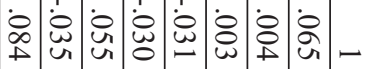
융. 安 光

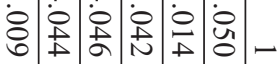
龸 윤 局 융

安

雨

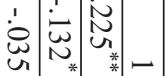

ن $\stackrel{\mathbb{T}}{\circ}$

市一 $\stackrel{\circ}{E}$ 
The over subscription is $8 \%$ on average that determines the equilibrium of market. This further describes that IPOs demand and supply sides are properly balanced. The numbers of independent non-executive directors were between 1 and 2 nonexecutive directors in board of directors of listed firm of AIM. The correlation matrix indicates that no variable is highly correlated with each other which further reduce the probability of multicollinearity among variables.

\subsection{Determinants of IPOs' long-run pricing performance}

To provide more comprehension and strength in the exploration of robust factors which are responsible for the long-run performance of IPOs, we also tested regression for each characteristic related to IPO process which explains the longrun performance of IPOs such as issue-specific, firm-specific, market-specific and governance-related characteristics and the simultaneously overall combination of these characteristics. Table 10 depicts that issue-specific factors suggest that underpricing and oversubscription from IPOs characteristics emerged as potential contributors of long-run performance of IPOs. Higher the underpricing more the probability of subsequent correction to adjust share prices in long-run phenomena resulting in substantial underperformance of IPOs.

In prior literature, various attempts have been made to test the fads in the IPO market (Fama et al., 1969; Bondt and Thaler, 1985; Aggarwal and Rivoli, 1990; Aggarwal, Leal and Hernandez, 1993) and impresario hypothesis (Chepeta and Jardine, 2014) using 'underpricing' as one of the explanatory variables in the regression model. Likewise, financial leverage and firm size from firm-specific characteristics come out as significant determinants of the long-run price performance of IPOs. On the other hand, the hot market period from market-specific characteristics shows a significant impact on the long-run price performance of IPOs. Similarly, In prior literature, various studies documented the nexus between hot issue market and IPO underperformance for instance(Ritter, 1998; Kaneko and Pettway, 2003; Khurshed, Kostas and Saadouni, 2016; Ali, 2017). IPOs going public in the hot issue period are overly optimistic growth prospects perform substantially worse than the other IPOs (Mumtaz, Smith, and Ahmed, 2016). 
Abdul Wahid, Muhammad Zubair Mumtaz • Long-run price performance of local...

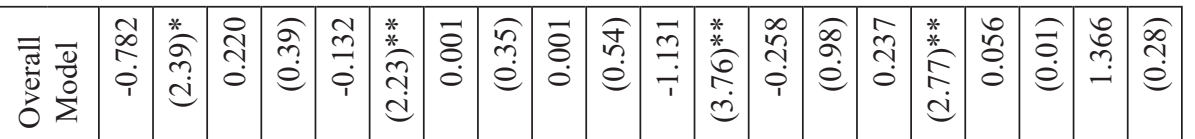

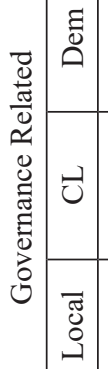

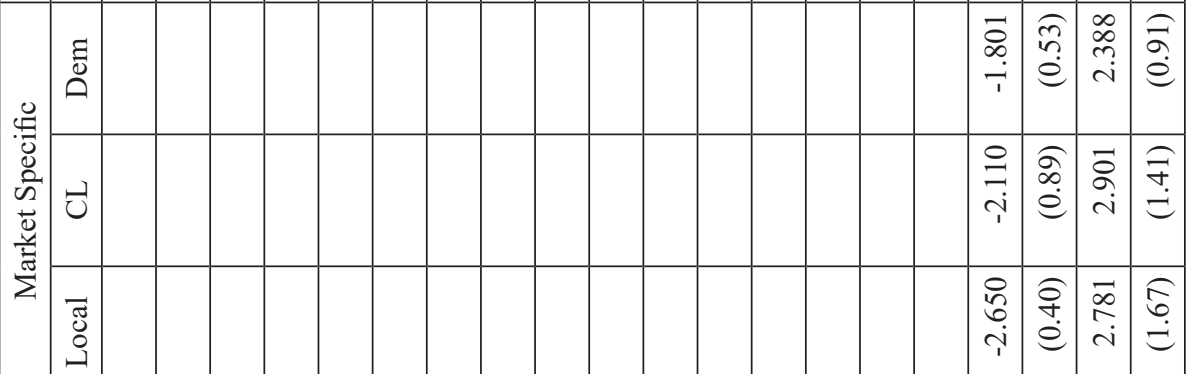

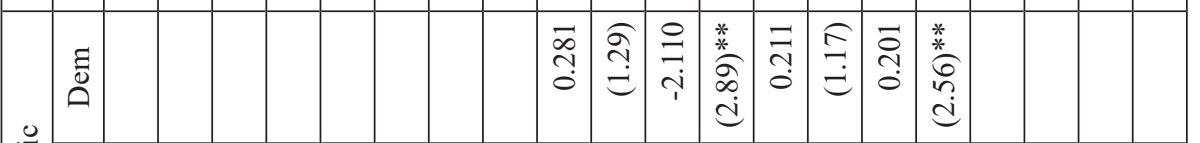

ט:

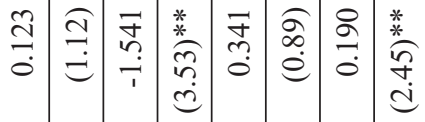

䛼

శ్

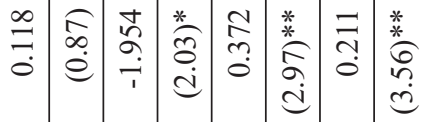

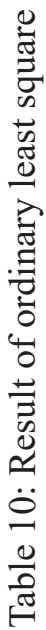

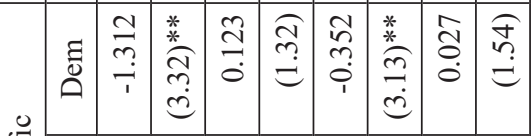

:

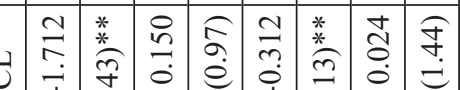

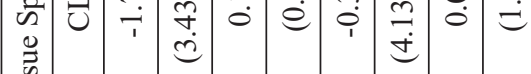

क

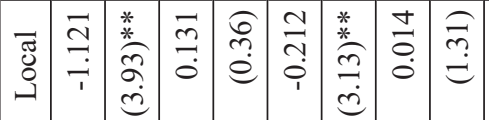

\begin{tabular}{|c|c|c|c|c|c|c|c|c|c|}
\hline S & 吾 & $\begin{array}{l}\overrightarrow{\overrightarrow{7}} \\
\text { ठे }\end{array}$ & $\begin{array}{l}\tilde{N} \\
\dot{w} \\
\dot{ \pm} \\
\mathbb{0}\end{array}$ & $\stackrel{\text { }}{\exists}$ & 总 & 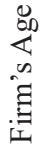 & 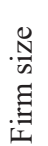 & $\begin{array}{l}\frac{\vec{v}}{\frac{1}{\Delta}} \\
\frac{\dot{y}}{\Sigma}\end{array}$ & $\begin{array}{l}\overrightarrow{0} \\
\frac{1}{y} \\
\sum\end{array}$ \\
\hline
\end{tabular}


Abdul Wahid, Muhammad Zubair Mumtaz • Long-run price performance of local...

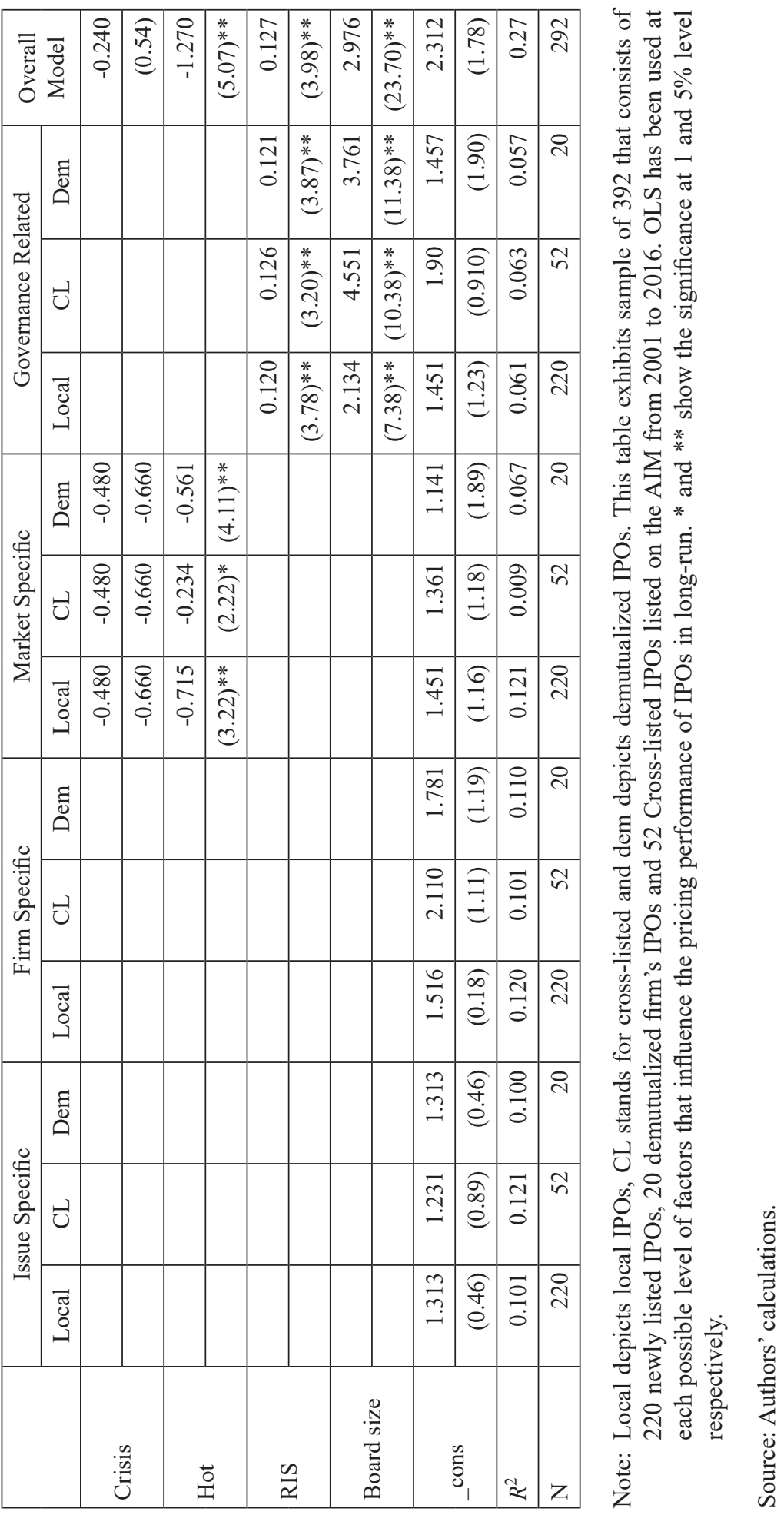


Likewise, there is a positive association between the long-run performance and the structure and strength of corporate governance in AIM. The result shows the significant impact of board size on long-run price performance. This ultimately provides an estimate of the agency's tradeoff magnitude to the insiders of the firm. The potential focus on the IPOs has allowed the researcher to investigate the role played by the governance when the firm begins to operate as a public company. If the firm has a more structured and independent board than the long-run performance would be better. This hypothesis supports the agency explaining the role of board independence in the long-run performance of IPOs.

\subsection{Result of EBA}

The estimation of EBA assumes that firm size is an important determinant in identifying the long-run performance of IPOs in AIM (Colombelli, 2010). Table 11 predicts that the size of the firm size inversely proportion to long-run performance which shows long-run underperformance of large-sized firms are expected to be lower in the presence of higher initial returns. This evidence corroborates the divergence of opinion hypothesis. When initial returns would be higher and the share prices revert to their equilibrium lowering the level of underperformance. Prior literature reported the positive relationship between underpricing and firm size which shows that underpricing decreases due to large-sized of the firm (Sahoo and Rajib 2010; Diro Ejara and Ghosh 2004; Mumtaz, Smith, and Ahmed 2016). The lower magnitude of underpricing causes the probability of subsequent correction takes place to adjust the long-run IPO prices that result in substantial underperformance.

The evidence relating to the domicile of IPOs illustrates that majority of small IPOs are incorporated and working in the London-based market. According to Amini, Keasey, and Hudson (2012), access to market-based equity finance is easier for London-based firms. Additionally, AIM is characterized by a substantial concentration of SMEs, most of which are located in the constituency of London. Considering the lower costs of start-up, the origination of these firms on innovative ideas as a new startup in universities and acceptance of these startups by Londonbased investors have the significant effect on the growth and survival of these firms (Amini and Keasey, 2013) which posit the higher probability of success of these small IPOs in AIM as compared to large-sized firms. 


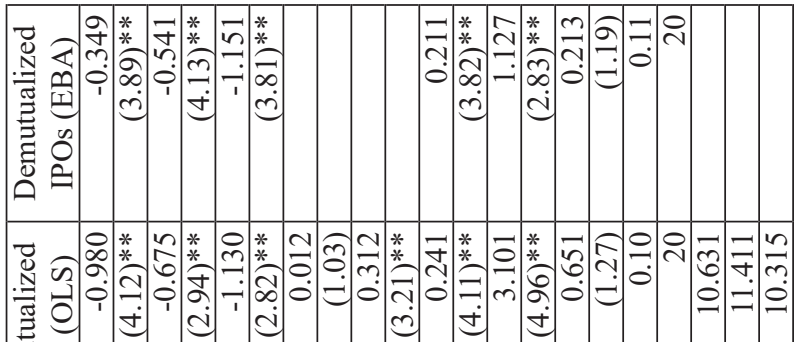
节

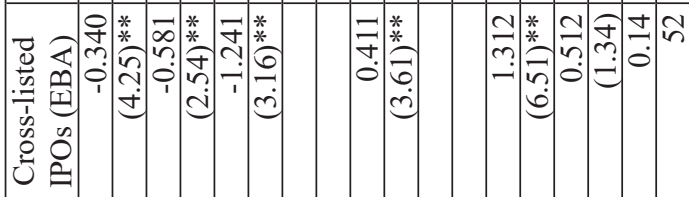

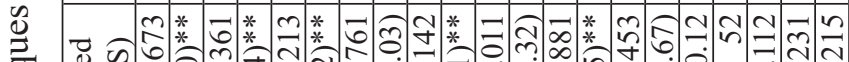

.

ల్

종

:을

త్ర

들

(1)

范

近

$\frac{\infty}{\infty}$

$\underline{2}$

突

定

苛

m

官

$\stackrel{\square}{x}$

II



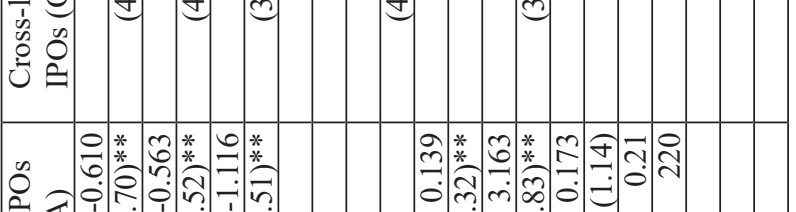

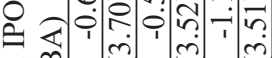
त्ञ

-

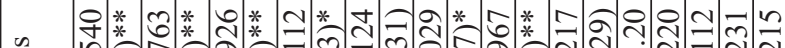
苜 चु

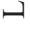

n

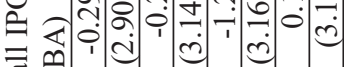
莺 勻

ठ

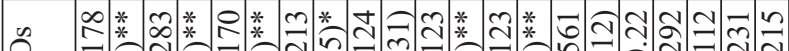
ڤ क
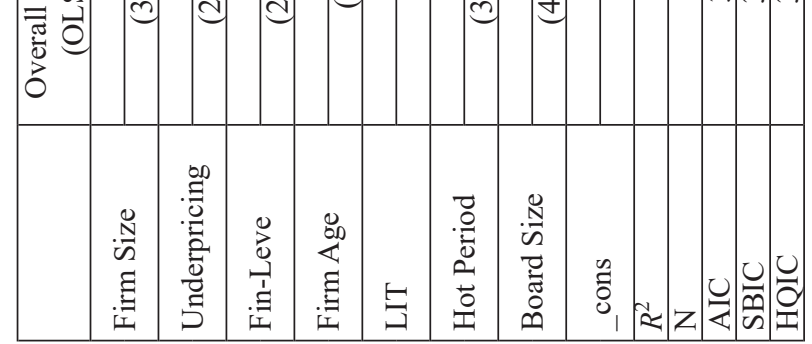

Ð

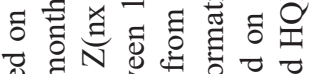
兽

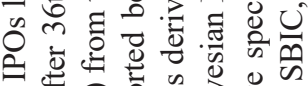

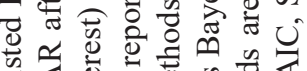

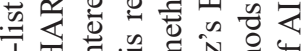

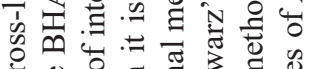
ษ ก

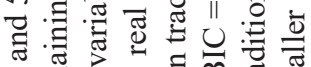

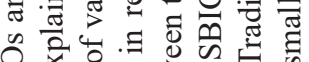

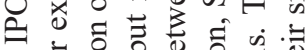

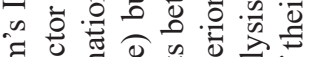

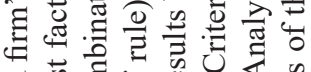

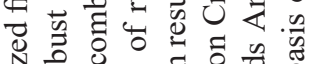

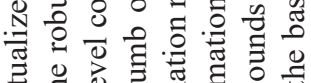

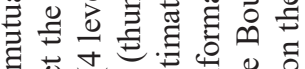
힘 율임 की

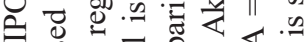
ठ워 氠

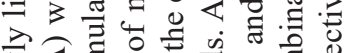

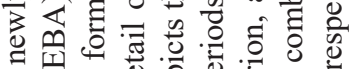

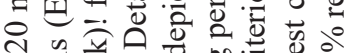
สิ $\frac{\pi}{4}$.

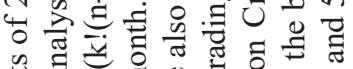

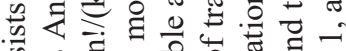

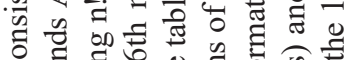
ठ

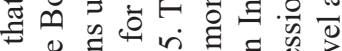
ํํำ

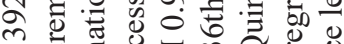

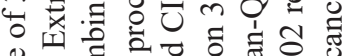

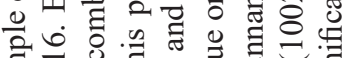

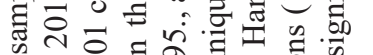

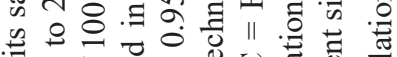

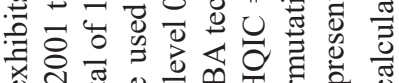

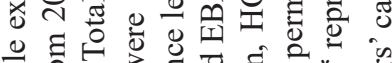
㐘

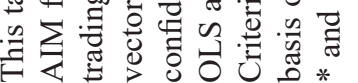
0
0
0
0
0
0
0
0 
The rationale behind this evidence is that new startup based on innovative and unique ideas, where public shareholders especially locally business graduates are involved in generating the financial synergies in the short-and long-run. The contemporary evidence suggests many factors influencing IPO ability to survive in the aftermarket for the long-run such as the size of the firm, age of the firm, industrial sector, and uniqueness of products and services marketed by the firm. According to Audretsch and Lehmann (2005), human capital knowledge and intellectual property of the firm has greater influences on the survival and growth of firm even that firm's ownership structure don't matter in long-run. This supports the findings of our study that the probability of growth and survival of small firms is higher relative to large firms in AIM which further produces the higher returns for small IPOs in the short- and long-run.

To measure the sensitivity and the robustness of the factors affecting the long-run performance of IPOs in an alternative market, we compare the results of the EBA technique with traditional methods which include the Akaike's information criterion (AIC), the Schwarz's Bayesian information criterion (SBIC) and the Hannan-Quinn information criterion (HQIC) as shown in Table 9. We select the lower values of information criteria and derive fewer variables related to market, firm, and issue specific characteristics. The application of the EBA technique finds that the model specification is limited to firm size, underpricing, financial leverage, firm age, hot market, and boar size. Alternatively, traditional techniques (e.g. AIC, SBIC, and HQIC) recommend firm size, underpricing, financial leverage, firm age, long-term investment ratio, hot market, and boar size selected based on the lower value of information criteria.

\section{Discussion of the results}

We report that IPOs over-performed in the long-run which shows that the alternative market is more favorable and provides conducive environment for new issues. This result is not consistent with previous IPO literature in the long-run except for the studies by Dutta (2016) and Bird and Ajmal (2016). The logic behind such type of findings is (a) AIM provides the more favorable environment, (b) no strict criterion to qualify for listing on AIM and ongoing trading, and (c) alternative market is dedicated to small enterprise and cross-listed IPOs. Also, the size of the firm has emerged as a robust predictor of the long-run performance of IPOs which shows that large-sized firms underperform less while the small-sized firms underperform more. Previous studies document the positive relationship between underpricing and firm size. This reflects that large-sized firms earn higher abnormal returns on a listing day (Sahoo and Rajib 2010; Diro Ejara and Ghosh 2004; Mumtaz, Smith, and Ahmed 2016). In short, large-sized firms provide a higher probability of subsequent correction of share prices in the long-run which results in substantial underperformance of new issues. 
Contrary to this, underpricing is negatively associated with long-term performance. If the underpricing is higher than the aftermarket performance of the IPOs will be lower (Mumtaz, Smith, and Ahmed, 2016; Pandya, 2016). As a result, the net impact of firm size on the long-run performance of IPOs is negative.

Last but not least, underpricing, financial leverage, hot IPO activity period, and the ratio of independent non-executive directors from issue-specific, firmspecific, market-specific and governance related characteristics respectively appear as potential factors affecting the long-run performance of IPOs. Higher the underpricing, more the possibilities of subsequent correction to settle down the share prices in the long-run which results in substantial underperformance. IPOs going public in the hot issue period are overly optimistic growth prospects perform substantially worse than the other IPOs (Mumtaz, Smith, and Ahmed 2016). If the firm has a more structured and independent board, then the long-run performance would be lower. This hypothesis supports the agency hypothesis explaining the role of board independence in the long-run performance of IPOs.

In short, the alternative investment market is functioning as an uplifting forum for SMEs. In the main market, these firms are not obtaining positive returns and their growth is also limited. Small firms face difficulty to earn positive abnormal returns in the main market. Ritter, Signori, and Vismara (2012) shed light on the phenomenon by exploring three reasons of low returns of small firms in the main market including (a) regulatory overreach- compliance costs of being a public listed company are higher in the main market, (b) market conditions hypothesis- small IPOs has been depressed by lower market valuations and (c) economies of scopesmall firms being acquired. The theoretical insights of our study are very useful for firms and portfolio investors in the second market. For future research, the role of corporate governance in the long-run performance of IPOs may be examined due to weak governance mechanism in the second market.

\section{Conclusion}

The study is deliberated upon to test the proposition of the long-run pricing performance of IPOs listed in the second market. For this purpose, the data of 292 IPOs has been used to test the proposition by applying the EBA technique. We report that IPOs earned significant positive abnormal returns for 36 months while the size of the firm has emerged as a robust predictor of long-run performance. The higher level of underpricing leads to a higher probability of subsequent price correction in the long-run thereby resulting underperformance of IPOs. Contrary to this, this study found the lower underpricing in the short-run and higher over performance in the long-run. We identified that underpricing, financial leverage, hot IPO activity period, and the ratio of independent non-executive director from 
issue, firm, market, and governance-related characteristics respectively appear as potential factors affecting the long-run performance.

Our evidence also supports the window of opportunity hypothesis, entrenchment theory, and fads hypothesis. It deduces that if the firm is going in public during the favorable market condition, it generates undue optimism in prospective investors about the performance of IPOs. In other words, aftermarket pricing performance of IPOs depends on the information about the intrinsic worth of IPO and investor's sentiment, which is publicly available in the market at the time of the offering. In short, noise traders are presumed to be higher return taker at the time of offering. They are more convinced or ready to pay the high prices (concerning the intrinsic value of IPO shares) to acquire the shares sold in the offering. Likewise, interconnections of board members with other stakeholders of firms, such as investors, investment banks, and regulators will positively influence the performance of an IPO firm.

For instance, independent board members with strong industry linkages can enhance the overall pace of firm for human and social capital and can also develop substantive functioning of the firm by providing access to information and strategic partnership with potential investment pools. This leads to the projection of optimistic views and perceptions among these stakeholders concerning the long-run performance of IPOs. Board members with social interlocks can also help to reduce "legitimacy deficit" that IPO firms suffer in the eyes of prospective investors and market analysts since "responsible look" of a firm represented on the board gives substantiation to the rest of investor's community of the intrinsic soft value and worth of the organization. Secondly, an empowered board can also eliminate the monopolist interference and involvement of management in the strategic decision making of a firm, which will ultimately add value in the long-run performance of IPOs. It is therefore suggested that the ratio of the independent non-executive director may be extended to get more fruitful results in the long-run. These findings suggest that prospective investors can develop and diversify their portfolio in an alternative market. The findings of the study have also practical value for those investors who are especially interested in earning abnormal excess returns in an alternative market.

\section{References}

Acedo-Ramírez, M. Á. and Ruiz-Cabestre, F. J. (2016) 'IPO characteristics and underprincing in the Alternative Investment Market', Applied Economics Letters. Routledge, Vol. 24, Issue 7, pp. 485-489. doi: 10.1080/13504851.2016.1205713.

Aggarwal, R., Leal, R. and Hernandez, L. (1993) 'The aftermarket performance of initial public offerings in Latin America', Lahore Journal of economics, 22(1), pp. 42-53. doi: 10.2307/3665964. 
Aggarwal, R. and Rivoli, P. (1990) 'Fads in the Initial Public Offering Market?', Source: Financial Management, 19(4), pp. 45-57. doi: 10.2307/3665609.

Ali, H. A. A. (2017) 'Behavioral Timing, Valuation and Postissue Performance of UK Initial Public Offerings', Journal of Behavioral Finance, 18(2), pp. 152166. doi: 10.1080/15427560.2017.1308938.

Amini, S. and Keasey, K. (2013) 'The failure of small British Initial Public Offerings on the UK Alternative Investment Market: A research note on spatial and industry effects', International Small Business Journal, 31(6), pp. 722-733. doi: $10.1177 / 0266242612458301$.

Amini, S., Keasey, K. and Hudson, R. (2012) 'The equity funding of smaller growing companies and regional stock exchanges', International Small Business Journal. doi: 10.1177/0266242610382931.

Audretsch, D. B. and Lehmann, E. E. (2005) 'The Effects of Experience, Ownership, and Knowledge on IPO Survival: Empirical Evidence from Germany', Review of Accounting and Finance. doi: 10.1108/eb043435.

Bird, R. and Ajmal, H. (2016) 'Mispricing of Australian IPOs', Journal of the Securities Institute of Austarlia, 1(April), pp. 26-33.

Bondt, W. F. M. De and Thaler, R. (1985) 'Does the Stock Market Overreact?', The Journal of Finance, 40(3), p. 793. doi: 10.2307/2327804.

Chahine, S. (2007) 'Block-holder ownership, family control and post-listing performance of French IPOs', Managerial Finance, 33(6), pp. 388-400. doi: $10.1108 / 03074350710748740$.

Chepeta, C. and Jardine, A. (2014) 'A Review Of The Determinants Of Long Run Share Price And Operating Performance Of Initial Public Offerings On The Johannesburg Stock Exchange', International Business \& Economics Research Journal, 13(5), pp. 1161-1176. doi: 10.3844/jssp.2009.188.192.

Colombelli, A. (2010) 'Alternative Investment Market: A Way to Promote Entrepreneurship', Journal of Industry, Competition and Trade, 10(3), pp. 253274. doi: 10.1007/s10842-010-0079-9.

Cooley, T. F. and Leroy, S. F. (1981) 'Identification and Estimation of Money Demand', American Economic Review, 71(5), pp. 825-844. Available at: http:// search.ebscohost.com/login.aspx?direct=true $\& d b=b t h \& A N=4507846 \&$ site $=$ eh ost-live\&scope $=$ site.

Diro Ejara, D. and Ghosh, C. (2004) 'Underpricing and aftermarket performance of American depositary receipts (ADR) IPOs', Journal of Banking and Finance, 28(12), pp. 3151-3186. doi: 10.1016/j.jbankfin.2004.05.006.

Doidge, C. and Stulz, R. (2007) 'Has New York Become Less Competitive in Global Markets? Evaluating Foreign Listing Choices Over Time', National Bureau of Economic Research. doi: 10.3386/w13079. 
Dutta, A. (2016) 'Reassessing the long-term performance of Indian IPOs', Journal of Statistics \& Management Systems, 0510 (February). doi: 10.1080/ 09720510.2015.1086174.

Fama, E. F. et al. (1969) 'The Adjustment Of Stock Prices To New Information The Adjustment Of Stock Prices To New Information', International economic review, 10(1), pp. 1-21. Available at: http://www.jstor.org/stable/2525569.

Fine, M. B., Gleason, K. and Mullen, M. (2017) 'Marketing spending and aftermarket performance of IPO firms', Marketing Intelligence and Planning, 35(4), pp. 560-576. doi: 10.1108/MIP-05-2016-0083.

Guo, R. J., Lev, B. and Shi, C. (2006) 'Explaining the short- and long-term IPO anomalies in the US by R\&D', Journal of Business Finance and Accounting, pp. 550-579. doi: 10.1111/j.1468-5957.2006.00610.x.

Hore, A. (2016) How AIM came of age. Available at: https://www.ii.co.uk/analysiscommentary/how-aim-came-age-ii379516.

Kaneko, T. and Pettway, R. H. (2003) 'Auctions versus book building of Japanese IPOs’, Pacific Basin Finance Journal, 11(4), pp. 439-462. doi: 10.1016/S0927538X(03)00049-0.

Khurshed, A., Kostas, D. and Saadouni, B. (2016) 'Warrants in underwritten IPOs: The Alternative Investment Market (AIM) experience', Journal of Corporate Finance. Elsevier B.V., 40, pp. 97-109. doi: 10.1016/j.jcorpfin.2016.07.010.

Kooli, M. and Suret, J.M. (2004) 'The Aftermarket Performance of Initial Public Offerings in Canada', Journal of Multinational Financial Management, 14(1), pp. 47-66. doi: 10.1016/S1042-444X(03)00038-0.

Leamer, E. E. (1983) 'Let's Take the Con out of Econometrics', American Economic Review, 73(1), pp. 31-43. doi: 10.2307/1803924.

Leamer, E. E. (1985) 'Sensitivity analyses would help', American Economic Review, pp. 308-313. doi: 10.1126/science.151.3712.867-a.

Lee, Y.-S. (2012) 'The determinants of cross-sectional liquidity in the IPO aftermarket', Applied Financial Economics, 22(14), pp. 1161-1173. doi: 10.1080/09603107.2011.633890.

Levine, R. and Renelt, D. (1992) 'A sensitivity analysis of cross-country growth regressions', American Economic Review, 82(4), pp. 942-963. doi: 10.2307/ 2117352.

Loughran, T. And Ritter, J. R. (1995) 'The New Issues Puzzle', The Journal of Finance, 50(1), pp. 23-51. doi: 10.1111/j.1540-6261.1995.tb05166.x.

Lyon, J. D., Barber, B. M. and Tsai, C.-L. (1999) 'Improved Methods for Tests of Long-Run Abnormal Stock Returns', The Jounal of Finance, 54(1), pp. 165201. doi: 10.1111/0022-1082.00101.

Mazzola, P. and Marchisio, G. (2002) 'The Role of Going Public in Family Businesses' Long-Lasting Growth: A Study of Italian IPOs', Family Business Review. doi: 10.1111/j.1741-6248.2002.00133.x. 
Mumtaz, M. Z, Smith, Z. A. and Ahmed, A. M. (2016) 'The Aftermarket Performance of Initial Public Offerings in Pakistan', The Lahore Journal of Economics, 21(1), pp. 23-68.

Mendoza, J. M. (2008) 'Securities Regulation in Low-tier Listing Venues : The rise of the Alternative Investment Market', Fordham Journal of Corporate \& Financial Law.

Miguel Á. Acedo-Ramírez and Francisco J. Ruiz-Cabestre (2017) 'IPO characteristics and underprincing in the Alternative Investment Market', Applied Economics Letters. doi: 10.1080/13504851.2016.1205713

Miller, E. M. (1977) 'Risk, Uncertainty, And Divergence Of Opinion', The Journal of Finance, 32(4), pp. 1151-1168. doi: 10.1111/j.1540-6261.1977.tb03317.x.

Miller, E. M. (2001) 'Why the low returns to beta and other forms of risk', Journal of Portfolio Management, 27(2), p. 40. doi: 10.3905/jpm.2001.319791.

Moosa, I. A. and Cardak, B. A. (2006) 'The determinants of foreign direct investment: An extreme bounds analysis', Journal of Multinational Financial Management, 16(2), pp. 199-211. doi: 10.1016/j.mulfin.2005.07.002.

Mudambi, R. et al. (2012) 'Multinationality and the performance of IPOs', Applied Financial Economics, 22(10), pp. 763-776. doi: 10.1080/09603107.2011.626396.

Pandya, F. H. (2016) 'After Market Pricing Performance of Initial Public Offerings (IPOs)', Jindal Journal of Business Research, 5(1), pp. 1-16. doi: 10.1177/ 2278682116670077.

Ritter, J. R. (1998) 'Initial public offerings', Contemporary Finance Digest, 2(1), pp. 5-30. doi: 10.1016/S0927-0507(05)80074-X.

Ritter, J. R. (1991) 'The Longrun Performance of initial Public Offerings', The Journal of Finance, 46(1), pp. 3-27. doi: 10.1111/j.1540-6261.1991.tb03743.x.

Ritter, J. R., Signori, A. and Vismara, S. (2012) Economies of Scope and IPO Activity in Europe, SSRN. doi: 10.2139/ssrn.2169966.

Sahoo, S. and Rajib, P. (2010) 'After market pricing performance of initial public offerings (IPOs): Indian IPO market 2002-2006’, Vikalpa, 35(4), pp. 27-43. doi: 10.1177/0256090920100403.

Wahid, A., Mumtaz, M. Z. and Mantell, E. H. (2019) 'Analyzing the Spillover Effects from Parental Markets to Cross-listed IPOs on Mean returns and Price Volatility', South Asian Journal of Management Sciences. doi: 10.21621/sajms. 2019132.04.

Wahid, A., Mumtaz, M. Z. and Mantell, E. H. (2020) 'Short-run Pricing Performance of Local and Dual Class IPOs in Alternative Investment Market', Romanian Journal of Economic Forecasting, 23(1), pp. 57-74. 


\title{
Dugoročna stabilnost razine cijena lokalnih i dvostrukih inicijalnih javnih ponuda (IPO-a) na tržištu alternativnih ulaganja
}

\author{
Abdul Wahid ${ }^{1}$, Muhammad Zubair Mumtaz ${ }^{2}$
}

\begin{abstract}
Sažetak
Ranija istraživanja potvrđuju da su inicijalne javne ponude (IPO) kratkoročno podcijenjene, a dugoročno daju slabe rezultate. U gotovo svim studijama istraživači analiziraju rezultate uspješnosti IPO-a koristeći skupove podataka visoko likvidnih tržišta. Međutim, cjenovno ponašanje IPO-ova na tržištu alternativnih ulaganja (AIM) je drugačije. S razlogom se očekuje da će se cjenovna uspješnost IPO-a na AIM-u značajno razlikovati od performansi IPO-a na tradicionalnim tržištima, ponajprije zbog smanjene likvidnosti AIM ponude, kao i zbog oskudnih informacija u usporedbi s tradicionalnim tržištima. Da bi testirali svoje tvrdnje, odabrali smo s popisa AIM-a 292 IPO-a u razdoblju između 2001. i 2016.godine i primijenili analizu ekstremnih granica (EBA) kako bismo utvrdili čimbenike koji utječu na dugoročne performanse. Ovo istraživanje potvrđuje da na alternativnim tržištima ulagači ostvaruju značajne pozitivne prinose ukoliko zadrže dionice u periodu od tri godine, a cjenovne razlike ovise o veličini poduzeća. Iz navedenog proizlazi da se ulaganje u mala poduzeća čini profitabilnijim u usporedbi s investicijama u velika poduzeća u AIM-u. Nadalje, $u$ ovom radu ispituju se statistički dokazi vezani uz pitanje mogu li prvi ulagači u IPO u dugom roku očekivati prekomjerno visoke prinose.
\end{abstract}

Ključne riječi: IPO, dugoročna stabilnost razine cijena, analiza ekstremnih granica, tržište alternativnih ulaganja (AIM)

JEL klasifikacija: G12, G14, C1

1 Predavač, NUML School of Business, National University of Modern Languages (NUML), Sector H-9, Islamabad, Pakistan. Znanstveni interes: financijska ekonomija. Tel.: +923112211990.E-mail: abwahid@numl.edu.pk

2 Izvanredni profesor, National University of Sciences \& Technology (NUST), School of Social Sciences \& Humanities (S3H), Sector H-12, Islamabad, Pakistan. Znanstveni interes: financijska tržišta i digitalizacija.Tel.: +925190853566.E-mail: zubair@s3h.nust.edu.pk. 